\title{
The Association of Cyp1a1 Gene Polymorphisms with Cyp1a1 Enzymes, P53 Protein, and Vascular Endothelial Growth Factor Levels in Pterygium
}

\author{
Hendriati $^{1}$, Yanwirasti ${ }^{2}$, Tjahjono Darminto Gondhowiardjo ${ }^{3}$, Djong Hon Tjong ${ }^{4}$ \\ $\left\{\right.$ hendriati@med.unand.ac.id ${ }^{1}$, yanwirasti@yahoo.com ${ }^{2}$, tgondh@yahoo.com ${ }^{3}$, tjong20@yahoo.com $\left.{ }^{4}\right\}$ \\ Ophthalmology Departement of Medical Faculty, Universitas Andalas, Padang -Indonesia ${ }^{1}$ \\ Biomedical Laboratory of Universitas Andalas, Indonesia ${ }^{2}$ \\ Ophthalmology Departement of Medical Faculty - University of Indonesia, Jakarta -Indonesia ${ }^{3}$ \\ Biological Faculty of Universitas Andalas, Padang, Indonesia ${ }^{4}$
}

\begin{abstract}
CYP1A1 gene, which has role in carcinogenic metabolisms, is also detected in pterygium tissue. We aim to determine the association between CYP1A1m1 (rs4646903) polymorphisms with the level of CYP1A1 enzymes, p53 protein, and vascular endothelial growth factor (VEGF) in patients with inflammatory and non-inflammatory pterygium. DNA isolation was performed from a blood sample of 70 pterygium patients consisting of 35 inflammatory and 35 noninflammatory pterygia. Rs 4646903 SNP Genotyping T> C $(\mathrm{m} 1)$ in the CYP1A1 gene was performed using restriction fragment length polymorphisms-PCR (RFLP-PCR). PCR products confirmed and sent to Macrogen, South Korea for sequencing. Polymorphism results are characterized as wild-type (TT), mutant homozygote (TC), and mutant heterozygote (CC). CYP1A1 gene polymorphisms consist of mutant heterozygote (TC), mutant homozygote (CC) and wild-type (TT). In both groups, the heterozygote mutant was higher than the wild-type and mutant homozygote. The CYP1A1 enzyme level was higher in inflammatory pterygium, P53 protein levels were higher in the non-inflammatory group, and VEGF levels were higher in the inflammatory group. CYP1A1 polymorphisms were not associated with CYP1A1 enzyme levels, p53 protein levels, and VEGF in both groups. CYP1A1 gene polymorphism has not been shown to be associated with levels of CYP1A1 enzymes, p53, and VEGF in both pterygium groups.
\end{abstract}

Keywords: Inflammation, Polymorphism Genetic, Pterygium.

\section{Introduction}

Pterygium is epithelial hyperplasia characterized by fibrovascular tissue growth on the ocular surface, which grows out of conjunctiva and proliferates all over the cornea. [1] The disease is closely associated with exposure to ultraviolet (UV)-B, primarily affect the stem cells in the limbus. Clinically, pterygium is associated with inflammation and neovascularization. Pterygium either primary or recurrent can cause changes in normal conditions such as astigmatism, and changes in the ocular surface, which eventually can lead to visual dysfunction due to decreased visual acuity. [2],[3],[4]

The pathogenesis of pterygium is still not fully understood. According to the previous studies, there is a relationship between pterygium with the involvement of environmental factors 
such as viral infections or oxidative stress, anti-apoptotic mechanisms, mechanisms of immunology, cytokines, growth factors, extracellular matrix modulators, genetic factors, and possibly other factors. [3],[4],[5],[6]

Pterygium clinical symptoms may be mild and often with no complaints at all (asymptomatic). However, some patients may also have complaints such as red-eye, inflammation or irritation, burning sensation, and foreign body sensation. Clinically, Donald Tan classified pterygium as atrophic, intermediate, and fleshy. In practice, complaints and symptoms of pterygium are composed of inflammatory and non-inflammatory. [2],[3],[4]

Pterygium has long been regarded as a chronic degenerative condition, but after the discovery of abnormal expression of $\mathrm{p} 53$ protein in the epithelium of pterygium, the pterygium is now regarded as an uncontrolled cell proliferation associated with ultraviolet, like tumors. P53 mutant has a direct or indirect effect of the increase in gene expression of growth by stimulating growth factors, such as Fibroblast Growth Factor (FGF), Epidermal Growth Factor (EGF) dan Vascular Endothelial Growth Factor (VEGF). [4],[7]

The most specific growth factor is the increase in VEGF. VEGF is a heparin-binding glycoprotein that plays an important role as a factor of vascular permeability and vasculotropine, especially in cell proliferation, inflammation, tissue remodeling, and angiogenesis. Currently, VEGF is considered one of the most important angiogenesis factors in the mechanism of pterygium formation. [7],[8]

Environmental pollutants such as Polycyclic Aromatic Hydrocarbons (PAHs) compounds are the result of incomplete combustion of organic materials derived from environmental carcinogens and are metabolized by different xenobiotic-metabolizing enzymes, one of which cytochrome P450 (P450 or CYP). This enzyme is mainly instrumental in the change of PAHs into more polar metabolites and soluble in water, so the metabolites formed can be excreted from the body. However, during the metabolic process, various metabolites of PAHs unstable and reactive can be formed, and these metabolites to attack DNA, causing toxicity and cell transformation. The polymorphism of CYP1A1 was previously found in pterygium tissue. Thus, it is stated that the carcinogenic process was also involved in the pathogenesis of pterygium. [9]

CYP1A1 is a sub-family 1 CYP gene superfamily, one of the important genes that encode enzymes metabolizing carcinogens, and is involved in the metabolism of carcinogenic PAHs. This gene has an important role in catalyzing the oxidative reaction Benzo (a) pyrene, which is one of the most important classes of PAHs, into reactive metabolites carcinogen. CYP1 These enzymes are responsible for the activation and detoxification of various metabolites of PAHs. [9],[10]

CYP1A1 allele polymorphisms of $\mathrm{m} 1$ in both inflammatory and non-inflammatory pterygium have been studied previously. Hendriati et al. (2017) classified pterygium based on its clinical symptoms into an inflammatory and non-inflammatory pterygium. The study found that CYP1A1 polymorphisms may occur in both pterygium groups although statistically, the differences between the two pterygium groups were not significant. [11]

This study aims to determine the association between CYP1A1ml (rs4646903) polymorphisms with the level of CYP1A1 enzymes, p53 protein, and vascular endothelial growth factor (VEGF) in patients with inflammatory and non-inflammatory pterygium. 


\section{Materials and Methods}

This study was an observational study with cross-sectional study comparative study design carried out in the Department of Ophthalmology Dr. M. Djamil General Hospital Padang, Community Health Center (BKIM) Padang, and private hospitals to collect samples. The examination of the variables studied was conducted in Biomedical Laboratory of Faculty of the Medicine Andalas University of Padang.

The study population was all pterygium patients. The study sample is part of the population that meets the inclusion and exclusion criteria, both for inflammatory and non-inflammatory pterygium. The approximate size of the minimum sample is calculated based on the formula of a hypothesis test of 2 different proportions. From that calculation, we obtained a minimum samples number of 34 people for each group.

The inclusion criteria were all patients diagnosed with primary pterygium both unilaterally and bilaterally, meeting the criteria of surgical indication, either clinical or cosmetic indications, not receiving anti-VEGF therapy or steroids in the last 2 weeks, and agreed to participate in this study. Exclusion criteria were patients suffering from anterior segment infection (conjunctivitis and keratitis) and patients suffering from other disorders in the conjunctiva, such as benign and malignant lesions of the conjunctiva.

\subsection{Isolation of Genomic DNA}

Genomic DNA was isolated from $300 \mu$ of a blood sample using GF-1 Blood DNA Extraction Kit Vivantis. DNA isolation was performed following the kit procedure consisting mainly of the sample preparation stage, cell lysis stage, DNA binding stage, leaching stage, and the elution stage of DNA.

\subsection{Genotyping rs4646903 $(\mathrm{T}>\mathrm{C})$}

Genotyping SNP rs4646903 T> C (m1) in the CYP1A1 gene was performed by the PCR (RFLPPCR) Restriction Fragment Length Polymorphism method. The PCR product was cut with $1 \mathrm{U}$ restriction enzyme $\mathrm{MspI}$ (side restriction $=\mathrm{C}^{\wedge} \mathrm{CGG}$ ) at $37^{\circ} \mathrm{C}$ for 3 hours. Then the results of the restriction were analyzed using electrophoresis on a gelose gel of $1.5 \%$ which had been dyed GelRed DNA, then observed with GelDoc. Individuals who have a wild-type rs4646903 genotype (TT allele) will produce DNA bands of $338 \mathrm{bp}$. Individuals who have the heterozygous rs4646903 genotype (TC allele) will produce DNA bands of $338 \mathrm{bp}, 209 \mathrm{bp}$, and $129 \mathrm{bp}$. Individuals who have genotype rs4646903 mutant homozygotes (CC allele) will produce DNA bands of $209 \mathrm{bp}$ and $129 \mathrm{bp}$. As confirmation of RFLP-PCR results, some samples of purified PCR products will be sent to Macrogen, South Korea for sequencing.

\subsection{VEGF examination of pterygium tissue}

VEGF examination was done using VEGF microplate (item A): 96 wells (12 strips x 8 wells) coated anti-human VEGF. 


\subsection{ELISA examination p53}

Examination of human p53 ELISA is the enzyme-linked immunosorbent in vitroassay for quantitative measurements of human p53 in serum, plasma, and supernatant cell cultures. This test uses specific antibodies to human p53 coated by 96 - well plates.

\subsection{Cytochrome P450 1A1 (CYP1A1) Examination}

For CYP1A1 examination, we used an immunoassay enzyme that can be used for quantitative measurements of CYP1A1 in human serum, plasma, tissue homogenate, and other biological fluids.

Univariate analysis is used to see the distribution of each variable and then presented in tables and diagrams. The data consisted of CYP1A1 gene polymorphism characteristics, CYP1A1, VEGF, and p53 protein levels in pterygium. After the independent variables and dependent variables are known, the bivariate analysis is performed to determine the relationship and significance, by testing Chi-Square, Kolmogorov-Smirnov, t-test, Mann Whitney, One Way ANOVA and Kruskal Wallis respectively with significance level $\mathrm{p}<0,05$.

\section{Results}

CYP1A1 polymorphism was obtained from DNA isolation from a specimen of $300 \mu \mathrm{L}$ of blood. Isolation of DNA consists of a sample preparation stage, cell lysis stage, DNA binding stage, the washing stage, and elution stage. Genotyping SNP rs4646903 T> C (m1) in the CYP1A1 gene was performed on all pterygium samples $(\mathrm{n}=70)$ using the PCR (RFLP-PCR) Restriction Fragment Length Polymorphism (RFLP-PCR) method at the Biomedical Laboratory.

Confirmation of RFLP-PCR results was carried out on several samples of PCR products that had been purified and sent to Macrogen, South Korea for sequencing. The results of sequencing data were then processed with Genious software. Individuals who have the wildtype rs 4646903 genotype (TT allele) will produce a DNA band measuring at $338 \mathrm{bp}$. Individuals who have genotype rs4646903 heterozygote (CT allele) will produce DNA bands measuring at $338 \mathrm{bp}, 209 \mathrm{bp}$, and $129 \mathrm{bp}$. Individuals who have mutant rs 4646903 homozygote genotype (CC allele) will produce DNA bands measuring at $209 \mathrm{bp}$ and $129 \mathrm{bp}$ (figure 1). 


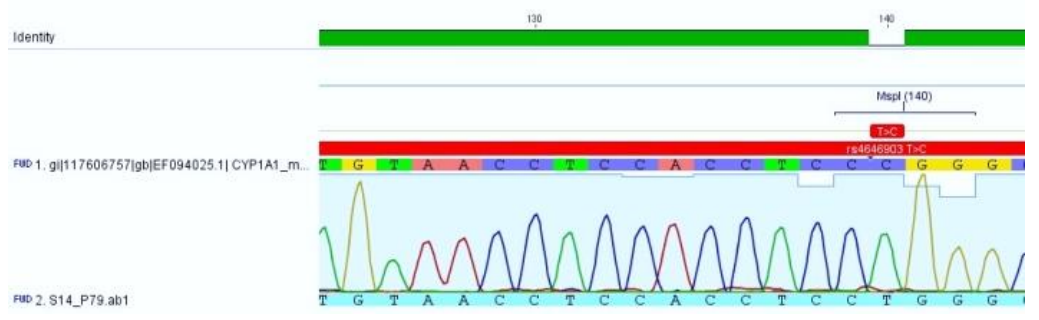

(a)

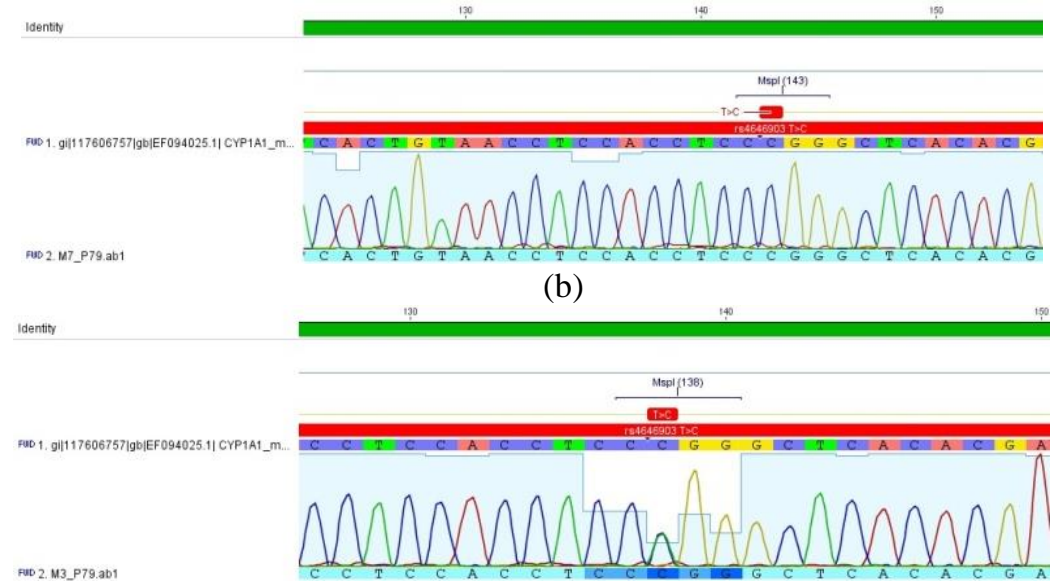

(c)

Fig. 1. Sequencing results from 3 DNA samples; (a) sample S14 shows the sequencing results confirmed $\mathrm{T}>\mathrm{T}$ wild-type, (b) sample M7 shows the sequencing results confirmed C>C homozygote, and (c) M3 shows the sequences confirmed by $\mathrm{T}>\mathrm{C}$ heterozygote

CYP1A1 polymorphisms found in inflammatory and non-inflammatory pterygium were further divided into wild-type, mutant homozygote, and mutant heterozygote. In both pterygium groups, mutant heterozygote polymorphisms were found to be higher than the wild-type and homozygote types, namely 34: 22: 14. Statistically, these differences were not significant as shown in table 1.

Table 1. CYP1A1 $m 1$ Polymorphism in Pterygium

\begin{tabular}{|c|c|c|c|c|}
\hline \multirow[b]{2}{*}{ Polymorphism } & \multicolumn{2}{|l|}{ Pterygium } & \multirow[b]{2}{*}{$\begin{array}{l}\text { Total } \\
\mathrm{f}(\%)\end{array}$} & \multirow[b]{2}{*}{$\mathrm{P}$} \\
\hline & $\begin{array}{l}\text { Inflammatory } \\
\mathrm{f}(\%)\end{array}$ & $\begin{array}{l}\text { Noninflammatory } \\
\mathrm{f}(\%)\end{array}$ & & \\
\hline Wild type (TT) & $12(54,5)$ & $10(45,5)$ & $22(100)$ & \multirow{4}{*}{$0,861^{*}$} \\
\hline Mutant Homozygote & $7(50,0)$ & $7(50,0)$ & $14(100)$ & \\
\hline Mutant Heterozygote & $16(47.1)$ & $18(52,9)$ & $34(100)$ & \\
\hline Total & $35(50)$ & $35(50)$ & $70(100)$ & \\
\hline
\end{tabular}

The level of CYP1A1 enzyme was obtained from pterygium tissue with DNA isolation, then examined using ELISA. Data analysis was performed using Independent Samples t-test presented in table 2 . 
Table 2. CYP1A1 Level in Inflammatory and Non-Inflammatory Pterygium

\begin{tabular}{llll}
\hline \multirow{2}{*}{ Variables } & \multicolumn{2}{c}{ Pterygium } & $\mathrm{p}$ \\
\cline { 2 - 3 } & $\begin{array}{l}\text { Inflammatory } \\
\text { Mean (SD) }\end{array}$ & $\begin{array}{l}\text { Non-inflammatory } \\
\text { Mean (SD) }\end{array}$ & $0,094^{*}$ \\
\hline $\begin{array}{l}\text { CYP1A1 Enzymes } \\
\text { Level }\end{array}$ & $0,15(0,06)$ & $0,13(0,07)$ & \\
\hline
\end{tabular}

*Independent Sample t-test

Based on table 2, the mean CYP1A1 enzyme level in the inflammatory pterygium group was higher than non-inflammatory pterygium, i.e. $0.15(0.06)$ versus $0.13(0.07)$. Statistically, the difference was not significant $(\mathrm{p}>0.05)$. P53 protein levels in pterygium tissue were obtained using ELISA. The data analysis was performed using Independent Samples t-test presented in Table 3, where the average p53 protein content in pterygium group was not inflamed higher than inflammatory pterygium, ie 13.66 (11.37) versus 13.21 (8.20). Statistically, the difference was not significant $(\mathrm{p}>0.05)$.

Table 3. Protein p53 Level in Inflammatory and Non-Inflammatory Pterygium

\begin{tabular}{lllll}
\hline \multirow{2}{*}{ Variables } & \multicolumn{3}{c}{ Pterygium } & $\mathrm{p}$ \\
\cline { 2 - 4 } & $\begin{array}{l}\text { Inflammatory } \\
\text { Mean (SD) }\end{array}$ & $\begin{array}{l}\text { Non-inflammatory } \\
\text { Mean (SD) }\end{array}$ & p \\
\hline $\begin{array}{l}\text { P53 protein } \\
\text { pterygium tissue }\end{array}$ & in & $13,21(8,20)$ & $13,66(11,37)$ & $1,00^{*}$ \\
\hline
\end{tabular}

* Independent Sample t-test

VEGF levels in pterygium tissue were obtained using ELISA. The data analysis was performed using Independent Samples t-test presented in table 4. The mean VEGF levels in the inflammatory pterygium group were higher than the non-inflammatory pterygium, ie 11.99 (7.24) versus 9.71 (5.14). Statistically, the difference was not significant ( $p>0.05)$.

Table 4. VEGF Level in Inflammatory and Non-Inflammatory Pterygium

\begin{tabular}{clll}
\hline \multirow{2}{*}{ Variables } & \multicolumn{2}{l}{ Pterygium } & \multirow{2}{*}{$\mathrm{p}$} \\
\cline { 2 - 3 } & $\begin{array}{l}\text { Mean inflammatory } \\
(\mathrm{SD})\end{array}$ & $\begin{array}{l}\text { Mean non-inflammatory } \\
(\mathrm{SD})\end{array}$ & $0,136^{*}$ \\
\hline VEGF level & $11,99(7,24)$ & $9,71(5,14)$ & \\
\hline$*$ Independent Sample t-test & &
\end{tabular}

* Independent Sample t-test

Data analysis of CYP1A1m1 polymorphism association with CYP1A1 enzyme level showed that CYP1A1 enzyme level in wild-type pterygium and mutant heterozygote group tends to be higher in an inflammatory group than non-inflammatory, whereas in a group with mutant homozygote polymorphism the mean value of CYP1A1 enzyme was higher in the noninflammatory group. Statistically, there was no correlation between CYP1A1m1 polymorphism with a mean value of enzyme CYP1A1 pterygium ( $p>0,05)$.

According to the polymorphism type, mean values of p53 protein in the inflammatory pterygium group tended to be higher in the mutant heterozygote group, whereas in the noninflammatory group the highest mean was in the wild-type group. Statistically, there was no 
correlation between CYP1A1m1 polymorphism with a mean value of $\mathrm{p} 53$ protein on pterygium $(\mathrm{p}>0,05)$.

The relationship of CYP1A1m1 polymorphism with VEGF levels as well, by type of polymorphism, the mean value of VEGF levels is higher in mutant homozygote than in wildtype or mutant heterozygote in the inflammatory group. In the non-inflammatory group, the mean value of the mutant homozygote was also higher than the other 2 groups. According to the pterygium group, the inflammatory group had a higher tendency than the non-inflammatory group. Statistically, there was no correlation between CYP1A1m1 polymorphism with a mean value of pterygium VEGF ( $\mathrm{p}>0,05)$.

\section{Discussion}

\subsection{CYP1A1m1 polymorphism (rs4646903) in inflammatory and noninflammatory Pterygium}

This study showed that CYP1A1 $\mathrm{m} 1$ gene polymorphism was found in both pterygium groups. Mutant heterozygote mutant polymorphism is a more common form of polymorphism in both groups compared to both homozygote and wild-type mutant forms. In both pterygium groups, each form of polymorphism was found to be almost similar in both inflammatory and noninflammatory pterygium, so there was no significant difference between the two groups.

Tung et al. (2010) studied the association of CYP1A1 allele variants and protein expression in primary culture epithelial cells. The association of CYP1A1 allele variants with CYP1A1 protein expression in the mutant homozygote $\mathrm{m} 2 / \mathrm{m} 2$ group was significantly higher than the wild-type $\mathrm{m} 1 / \mathrm{m} 1$ and mutant heterozygote $\mathrm{m} 1 / \mathrm{m} 2(\mathrm{p}=0.027)$. In the control group of normal conjunctive tissue, there was no significant relationship. Tung's study did not match with this study where the mutant heterozygote group is higher. [12]

\subsection{Different levels of CYP1A1 enzyme in inflammatory and noninflammatory Pterygium}

This study found that the average CYP1A1 enzyme level in the inflammatory pterygium group was higher than that of the non-inflammatory pterygium group, but no statistically significant difference was found.

The study by Tung et al. (2010) found a correlation between CYP1A1 polymorphism with BPDE-like DNA adduct formation in pterygium samples. Benzo [a] pyrene 7.8-diol 9.10epoxide (BPDE), is the main metabolite benzo [a] pyrene that has a relationship with CYP1A1. Immunohistochemical analysis was performed to determine the expression of CYP1A1 protein. In the pterygium group, $48(33 \%)$ samples were positive for CYP1A1 expression. Only $4 \%$ (2 of 50) of normal conjunctival samples shows CYP1A1 expression. CYP1A1 expression was higher in the pterygium group than in the control group $(\mathrm{p}<0.0001)$. [12]

Cytochrome-P450 1A1 (CYP1A1) is included in the important superfamily of cytochrome P450 (CYPs) involved in the metabolism of many xenobiotic compounds and endogenous lipophilic substances, which can activate procarcinogen into DNA reactive metabolites ${ }^{13,14}$. The human CYP1A1 gene is located on chromosome 15q22-24, composed of seven exons responsible for procarcinogen activation of reactive metabolites and is involved in oxidation mediation, including polycyclic aromatic hydrocarbons and aromatic amino to mutagenic and 
carcinogenic metabolites. CYP1A1 genetic polymorphism may cause changes or loss of CYP1A1 enzyme activity, and result in cellular detoxification damage, which can lead to the absence of cell growth suppression mechanisms. [15],[16]

\subsection{Differences in p53 protein levels in inflammatory and noninflammatory Pterygium}

Pterygium has long been regarded as a chronic degenerative condition, but after the discovery of abnormal expression of p53 protein in the pterygium epithelium, the pterygium is now considered an uncontrolled cell proliferation associated with ultraviolet, tumor-like rays. [4],[7] Under normal circumstances, p53 protein is at very low levels and achieves measurable levels if mutated. [17]

The results of this study showed no significant differences between p53 protein levels in inflammatory pterygium and not inflammation. P53 mutants have a direct or indirect effect on increasing the expression of growth genes by stimulating growth factors or growth receptors. P53 mutants proven to activate Fibroblast Growth Factor (FGF), Epidermal Growth Factor (EGF) and Vascular Endothelial Growth Factor (VEGF). Increased expression of growth genes plays an important role in cell proliferation, inflammation, connective tissue remodeling, and angiogenesis, and this may explain the variation in clinically visible growth. [16],[18]

\subsection{Differences in VEGF levels in inflammatory and noninflammatory Pterygium}

Growth factors have been shown to increase in pterygium, playing an important role in cell proliferation, inflammation, connective tissue remodeling, and angiogenesis. VEGF is present in the corneal layer, the vascular endothelium, and in macrophage infiltrate in inflamed corneas and neovascularization. The corneal limbus acts as a barrier between the conjunctival epithelium and the corneal epithelium. In the limbus, there is a stem cell that prevents the abnormal growth of the conjunctival epithelium to the cornea. In the pterygium, there is a disorder of the limbus barrier so that the conjunctival epithelium undergoes angiogenesis. The increase in VEGF regulation on pterygium is thought to be related to UVB radiation inducing VEGF transcription. [19]

The results of this study showed no significant difference between VEGF levels in inflammatory and noninflammatory Pterygium. A study by Peng et al. (2014) showed significantly higher levels of VEGF in pterygium epithelial cells than normal conjunctival epithelium. There is a correlation between pterigium and VEGF polymorphisms in VEGF 936 C> T (rs3025039), which is an important risk factor in pterygium. Study by Aspiotis et al (2005) found high expression of VEGF in conjunctival epithelium with higher mean microvascular number compared with normal conjunctiva. VEGF expression is mostly in endothelial cells and pterygium stroma, but not in epithelial cells. The accumulation of VEGF in epithelial cells represents production, whereas accumulation in endothelial and stromal cells describes the angiogenic activity. [20],[21]

\subsection{The association of CYP1A1m1 polymorphism with CYP1A1, p53 and VEGF levels in inflammatory and noninflammatory pterygium}

There was no significant correlation between CYP1A1m1 polymorphism with a mean of CYP1A1, p53, and VEGF enzyme levels in pterygium in both inflammatory and noninflammatory group. This is supported by the result of Peng (2014) and Young (2010) 
studies where the CYP1A1 protein expression of the $\mathrm{m} 1 / \mathrm{m} 1$ genotype was not more significant than the $\mathrm{m} 2 / \mathrm{m} 2$ genotype. [20],[22]

According to a study conducted by Peng et al. (2014) on the activity of CYP1A1 protein associated with allele variation in pterygium and cell tissues, it was found that variation of CYP1A1 allele could cause high BPDE-like DNA adduct formation rate, contributing to pterygium risk. However, it was also found that the pterygium risk was 2,339-fold greater for individuals with genotype $\mathrm{m} 2 / \mathrm{m} 2(\mathrm{C} / \mathrm{C})$ than individuals with genotype $\mathrm{C} / \mathrm{T}(\mathrm{m} 1 / \mathrm{m} 2)$ and $\mathrm{T} / \mathrm{T}$ $(\mathrm{m} 1 / \mathrm{m} 1)$. Meanwhile, according to Young et al. (2010) pterygium risk was 1.553 times greater. [20],[22]

\section{Conclusion}

The results of this study indicate the presence of polymorphisms in the CYP1A1 gene either in the form of mutant homozygote (CC), mutant heterozygote (TC), and wild-type (TT). Mutant heterozygote is the most common form of polymorphism between the two groups of inflammatory and non-inflammatory groups. The mean levels of CYP1A1 enzyme and VEGF levels in inflammatory pterygium tissue were higher than non-inflammatory pterygium while the higher $\mathrm{p} 53$ protein level in pterygium was found in noninflammatory pterygium compared to inflammatory pterygium, but statistically, the difference was not significant. CYP1A1 gene polymorphisms have not been shown to be associated with levels of CYP1A1 enzymes, p53 protein and VEGF level in both pterygium groups.

\section{References}

[1] Kaufman, S. C., Jacobs, D. S., Lee, W. B., Deng, S. X., Rosenblatt, M. I. \& Shtein, R. M. 2013. Options and Adjuvants in Surgery for Pterygium: A Report by the American Academy of Ophthalmology. Ophthalmology, 120, 201-8.

[2] Hirst, L. W. 2009. Recurrent Pterygium Surgery Using Pterygium Extended Removal Followed by Extended Conjunctival Transplant: Recurrence Rate and Cosmesis. Ophthalmology, 116, 1278-86.

[3] Bradley, J. C., Yang, W., Bradley, R. H., Reid, T. W. \& Schwab, I. R. 2010. The Science of Pterygia. Br J Ophthalmol, 94, 815-20.

[4] Detorakis, E. T., Zaravinos, A. \& Spandidos, D. A. 2010. Growth Factor Expression in Ophthalmic Pterygia and Normal Conjunctiva. Int J Mol Med, 25, 513-6.

[5] Zhivov, A., Beck, R. \& Guthoff, R. F. 2009. Corneal and Conjunctival Findings after Mitomycin C Application in Pterygium Surgery: An in-Vivo Confocal Microscopy Study. Acta Ophthalmol, 87, 166-72.

[6] Khakshoor, H., Razavi, M. E., Daneshvar, R., Shakeri, M. T., Ghate, M. F. \& Ghooshkhanehi, H. 2010. Preoperative Subpterygeal Injection Vs Intraoperative Mitomycin C for Pterygium Removal: Comparison of Results and Complications. Am J Ophthalmol, 150, 193-8.

[7] Balci, M., Şahin, Ş., Mutlu, F. M., Yağci, R., Karanci, P. \& Yildiz, M. 2011. Investigation of Oxidative Stress in Pterygium Tissue. Molecular Vision, 17, 443-447.

[8] Chowers, I., Pe'er, J., Zamir, E., Livni, N., Ilsar, M. \& Frucht-Pery, J. 2001. Proliferative Activity and P53 Expression in Primary and Recurrent Pterygia. Ophthalmology, 108, 985-8.

[9] Shimada, T. 2006. Xenobiotic-Metabolizing Enzymes Involved in Activation and Detoxification of Carcinogenic Polycyclic Aromatic Hydrocarbons. Drug Metab Pharmacokinet, 21, 257-276.

[10] Balaji, L., Singh, K. B. \& Bhaskar, L. V. K. S. 2012. Cyp1a1 Genotypes and Haplotypes and Risk of Oral Cancer: A Case-Control Study in South Indians. Genetics and Molecular Biology, 35, 407-412. 
[11] Hendriati, Yanwirasti, Gondhowiardjo, T.D., Tjong, D.H. 2017. CYP1A1 Gene Polymorphism in Inflammatory and Non Inflammatory Pterygium. Journal of Medical Science. 17 (1): 26-30.

[12] Tung, J. N., Wu, H. H., Chiang, C. C., Tsai, Y. Y., Chou, M. C., Lee, H. \& Cheng, Y. W. 2010. An Association between Bpde-Like DNA Adduct Levels and Cyp1a1 and Gstm1 Polymorphisma in Pterygium. Mol Vis, 16, 623-9.

[13] Shehadeh-Mashor, R., Srinivasan, S., Boimer, C., Lee, K., Tomkins, O. \& Slomovic, A. R. 2011. Management of Recurrent Pterygium with Intraoperative Mitomycin $\mathrm{C}$ and Conjunctival Autograft with Fibrin Glue. Am J Ophthalmol, 152, 730-2.

[14] Shimada, T. 2006. Xenobiotic-Metabolizing Enzymes Involved in Activation and Detoxification of Carcinogenic Polycyclic Aromatic Hydrocarbons. Drug Metab Pharmacokinet, 21, 257-276.

[15] Jaworski, C. J., Aryankalayil-John, M., Campos, M. M., Fariss, R. N., Rowsey, J., Agarwalla, N., Reid, T. W., Dushku, N., Cox, C. A., Carper, D. \& Wistow, G. 2009. Expression Analysis of Human Pterygium Shows a Predominance of Conjunctival and Limbal Markers and Genes Associated with Cell Migration. Mol Vis, 15, 2421-34.

[16] Lai, T. J., Tsai, Y. Y., Cheng, Y. W., Chiang, C. C., Lee, H., Chou, M. C. \& Chang, J. H. 2006. An Association between Bpde-Like DNA Adduct Levels and P53 Gene Mutation in Pterygium. Mol Vis, 12, 1687-91.

[17] Pelit, A., Bal, N., Akova, Y. A. \& Demirhan, B. 2009. P53 Expression in Pterygium in Two Climatic Regions in Turkey. Indian J Ophthalmol, 57, 203-6.

[18] Bianchi, E., Scarinci, F., Grande, C., Plateroti, R., Plateroti, P., Plateroti, A. M., Fumagalli, L., Capozzi, P., Feher, J. \& Artico, M. 2012. Immunohistochemical Profile of Vegf, Tgf-Beta and Pge(2) in Human Pterygium and Normal Conjunctiva: Experimental Study and Review of the Literature. Int J Immunopathol Pharmacol, 25, 607-15.

[19] Cardenas-Cantu, E., Zavala, J., Valenzuela, J., Valdez-Garcia, J. 2014. Molecular Basis of Pterygium Development. Seminars in Ophthalmology, 1-17.

[20] Peng ML, et al. 2014. Vascular endothelial growth factor gene polymorphism and protein expression in the pathogenesis of pterygium. British Journal of Ophthalmology. 98(4):556-61

[21] Aspiotis, M., Tsanou, E., Gorezis, S., Ioachim, E., Skyrlas, A., Stefaniotou, M. \& MalamouMitsi, V. 2007. Angiogenesis in Pterygium: Study of Microvessel Density, Vascular Endothelial Growth Factor, and Thrombospondin-1. Eye (Lond), 21, 1095-101.

[22] Young, C.-H., et al. 2010. Cyp1a1 Gene Polymorphisms as a Risk Factor for Pterygium. Molecular Vision, 16, 1054-1058. 